\title{
BIOLOGICAL ASSET: WHAT IS THE IMPACT ON AGRICULTURAL COMPANIES?
}

\author{
Maulida Dwi Kartikasari, Dien Noviany Rahmatika, Sumarno \\ Accounting Department, Pancasakti University, Jalan Halmahera KM 1 Tegal \\ Email: maulidadwikartikasari@upstegal.ac.id
}

\begin{abstract}
This study aims to determine the effect of managerial stock, biological asset intensity and firm size on the disclosure of biological assets in agricultural companies listed on the Indonesian stock exchange in 2016-2019. Population in this study were primary consumer goods sector companies in agricultural companies listed on the Indonesia Stock Exchange. Based on sample selection, there are 52 companies that required The data analysis technique usedin this research was the multiple linear regression analysis.. Based on the multiple linear regression analysis, the results show biological asset intensity have a significance below 0.05, namely 0.006. This shows that biological asset intensityhave a significant positive effect on biologiocal asset disclosure. However, the firm size and managerial ownership variables have a significance value above 5\%. This means that the two variables do not have a significant effect on biological asset disclosurein agricultural companies listed on the Indonesia Stock Exchangein 2016-2019.
\end{abstract}

Keywords : managerial stock, biologicall asset intensity, firm size, biological asset disclosure.

DOI: http://dx.doi.org/10.29040/jap.v22i1.2592

\section{INTRODUCTION}

Indonesia is a tropical country with abundant natural resources. Agriculture is divided into several sub-sectors, namely livestock, forestry, fisheries, horticulture, floriculture and plantations(Trina, 2017). Natural commodities or what we know as agriculture are a real impact of the abundance of natural resources in Indonesia. Factors such as geography, geology and astronomy are the forming facts of the abundance of biodiversity in Indonesia. agricultural sector plays an important role for the economic progress of countries in the Southeast Asian region because the majority of export commodities that ASEAN countries rely on are agricultural products. The geographic location and climate are not much different which causes countries in the Southeast Asia region to have similarities in the natural resources produced (Abrar, 2019). Agriculture has become a strategic objective to improve the standard of living of the Indonesian people in relation to the provision of food. By utilizing existing natural resources, Indonesian people can plant various kinds of agriculture and take these products. The characteristics that distinguish this plantation industry from other sectors are to produce products that are consumed or processed more than activities shown by biological changes in crops and management, these changes require a measurement of agricultural companies in order to show assets fairly and in accordance with contribution of the company to make a profit. BPS data states that in 2015-2017 the performance of agricultural development can boost the national economy. For the plantation sector in 2015 it was $2.9 \%, 2016$ was $3.42 \%$ and 2017 was $5.40 \%$, for the horticulture sector in 2015 it was $1.51 \%, 2016$ was $2.80 \%$ and in 2017 it was $4.80 \%$ while for sub-3 the livestock sector in 2015 amounted to $2.1 \%, 2016$ amounted to $1.6 \%$ and in 2017 amounted to $4.80 \%$. However, when we explore more deeply about the agricultural sector, the one with the best level is in the plantation sub-sector. The main GDP commodities of the plantation sub-sector include coffee, cocoa, coconut, sugarcane rubber, and also palm oil. As for the livestock sub-sector, such as poultry, large, small livestock and milk. And the GDP of the horticulture 
sub-sector is chilies, bananas, shallots and potatoes (Putri \& Siregar, 2019).

The Covid-19 pandemic still has an impact on all aspects of national economic life and even the world. The decline occurred in a number of economic sectors. When other sectors experienced a decline or slowdown, in contrast to the agricultural sector, it actually increased in the second and third quarters of 2020. In the second quarter the GDP of the agricultural sector grew $16.24 \%$ and in the third quarter it grew $2.15 \%$. The growth of the agricultural sector at the same time makes its contribution to the national economy continue to strengthen. This can be seen from the increase in the contribution to the GDP in the third quarter which increased to 571.87 trillion rupiah or $14.68 \%$ (Ditjenbun, 2020)

One of the main pillars of the positive growth of GDP in the agricultural sector last quarter was the plantation sub-sector, with a contribution in the third quarter of IDR 163.49 trillion or $28.59 \%$. This is due to an increase in demand for plantation commodities such as cocoa, rubber, tobacco and cloves as well as an increase in foreign demand for palm oil (CPO) processed commodities. Based on data conducted by the Central Statistics Agency (BPS), plantation exports in the January-October 2020 period amounted to 359.5 trillion Rupiah, an increase of $11.6 \%$ compared to the same period in 2019 of 322.1 trillion. With such a value, the plantation sub-sector became the largest contributor to exports in the agricultural sector with a contribution of 90.92 percent. The export of plantation commodities which surged in January-October was contributed most by rubber, palm oil, cocoa, coconut and coffee. The highest plantation export occurred in October, amounting to 38.46 trillion Rupiah with an increase of 8.76 percent from the previous month (Ditjenbun, 2020). The phenomenon that occurs in agricultural companies in Indonesia. is related to the disclosure of biological assets by these companies which are not in accordance with PSAK-69. Disclosure of biological assets is carried out in the annual report, as well as other accounting policies, which are in PSAK-69 which includes recognition, disclosure and measurement (Sa'diyah et al., 2019). In a company there must be transparency because the level of transparency will increase by disclosing more information in the financial statements ( $\mathrm{Al} \& \mathrm{Ahmed}$, 2012).

In a flexible sense, disclosure is the release of information. Disclosure is a quantitative information as well as other information, financial and nonfinancial information carried out by a company as communication information to reflect the company's performance and position. This information is presented in the form of financial statements that are used by internal and external parties in the decision making process. In order for the information in financial statements to be understood and not misinterpreted by users of financial statements, the presentation must be accompanied by disclosures (Hayati, 2020).The fact is that there are still companies that do not disclose information in accordance with the accounting practices required by users. This exposes users to inappropriate circumstances or has difficulty making their judgment decisions.

Biological assets are animals or plants that can produce agricultural assets. Any living plant or animal that can produce agricultural assets can be called biological assets. Plant and animal assets are called biological assets, why are they said to be biological assets because they undergo biological transformation (Utomo\&Khumaidah, 2014). For example, if a company produces and sells cow's milk as the main product, for example, cows are known as a biological asset and milk is an agricultural asset. Apart from understanding, PSAK 69 also presents items that must be included in the disclosure of biological assets, both mandatory and additional.

The standard requires proper disclosure of biological assets, in order to provide reliable and accurate information, so as not to harm the users of the information. Because, biological transformation allows the information presented by agricultural companies to be more savage than companies in other sectors. This is because the true value of assets tends to change along with the transformation of these assets (Eltanto, 2014).In practice, the achievement of financial performance inagricultural sector companies, in this case, is that the forestry sectoris very much influenced by the accounting policies of the forestplant assets (Hidayah and Zarkasyi, 2017)

According to IAS 41, a biological asset is defined as a biological asset is a living animal or plant According to Safitri (2013) there are changes or biological transformations in biological assets. According to Ridwan (2011) the unique nature of biological assets results in several time outcomes, namely degeneration (decrease in value in quantity or deterioration in the quality of biological assets, 
growth) (increase in quantity or improvement in the quality of biological assets). The transformation of biological assets such as dynamic physical, changes in size, age and amount affects the economic value and benefits of the assets themselves.

According to Safitri (2013) biological assets can be grouped into 2 types based on their useful life, namely long-term biological assets, long term biological assets, which are biological assets that have a useful life with a term of more than one period. For example, these assets are animals or plants that can be harvested or sold for more than one period, such as fruit-producing crops such as guava, durian, mango, apples and others. And long-lived livestock such as donkeys, cows, horses, goats etc., then shortterm biological assets are biological assets in the form of animals or plants that can be harvested or sold during the first or second year after breeding such as chickens, fish, duck, corn, rice and others. According to Ridwan (2011) there are 2 types of biological assets, namely biological assets of basic materials, for example wood production as paper material and inherited biological assets such as wool production from sheep.

Realizing the importance of provisions that specifically regulate the disclosure of biological assets, the Indonesian Institute of Accountants' Financial Accounting Standards board (2018) decided to adopt IAS 41 Agriculture by issuing the Exposure Draft (ED) PSAK 69 on agriculture and it was ratified on December 16, 2015. PSAK 69: Agriculture effective to be applied to the financial statements of agricultural companies on January 1, 2018. In Indonesia Aliffatun\&Sa'adah (2020) The contents of this PSAK-69 are about the accounting treatment of agricultural companies which includes reporting of biological assets, presentation, disclosure and measurement. Previously, there was PSAK-69, first there was PSAK-16 regarding fixed assets as a reference for agriculture in Indonesia (Kusumadewi, 2018).

Disclosure of biological assets will increase along with the increase made by agricultural companies that occur in the intensity of these biological assets. Duwu et al. (2018). biological asset intensity is an illustration of how much the proportion of company investment to biological assets in a company (Alfiani\&Rahmawati, 2019). According to Gonçalves \& Lopes (2014), biological asset intensity can also describe the expectation of cash received if the asset is sold. if a company has a high biological asset value, the company will make disclosures in the notes to the financial statements (Putri \&Siregar, 2019).

The purpose of asset disclosure is to serve various parties who have different interests and also to achieve the objectives of financial statements (Suwardjono, 2014: 580). The entity's disclosure of assets is immature biological assets, mature biological assets, bearer biological assets, and consumable biological assets. All of them are differentiators from quantitative descriptive disclosures of biological assets (PSAK-69, 2018).Accordingto the Zahroh and Hamidah, (2017) CGPI positively affectsprofitability, leverage has a negative influence on profitability,and company size negatively affects profitability. Accordingto Dzingai and Fakoya (2017), corporate governance affectsfinancial performance, and also proved too that it also positivelyinfluences business performance

Regarding research on the disclosure of biological assets, it has not been done much as an object of research (Kusumadewi, 2018). The results of research conducted by Hayati (2020) say that biological asset intensity has a positive effect on the disclosure of biological assets. Firm size according to Aliffatun\&Sa'adah (2020) states that company size affects the disclosure of biological assets. According to Gustria\& Sebrina (2020), the firm size has a positive effect on the disclosure of biological assets. Meanwhile, managerial ownership according to Putra (2019) stated that managerial ownership has no effect on disclosure of biological assets. this research period from 2016-2019. The reason for choosing this research period is because in that year there was an increase in economic growth in the agricultural subsector of the plantation sector. In addition, this study uses plantation companies, whereas in previous studies, all sectors of agricultural companies are used. The reason the researchers chose a plantation company was a tendency that was more complicated in managing their biological assets in the plantation sector company.

\section{Agency Theory}

Jensen and Meckling (1976) explain agency theory is a contractual relationship involving two or more parties. The two parties are the agent and principal. An agent is a party (management) who is trusted, given the authority and responsibility from the shareholders to control the company in order to achieve the wishes of the shareholders. The principal 
parties in this case are shareholders (Kurnia and Anis, 2017). This theory is a business reference and a basic foundation in the company. This agency theory describes the relationship or correlation between the agent (management) and the principal in the cooperation agreement or nexus of contract (Siddiq et al, 2017).

According to this theory, the correlation or relationship between the principal (shareholder) and the agent (management) is difficult to materialize because of a conflict of interest. This conflict of interest causes distrust of each other because the agent will prioritize his personal interests and underestimate the interests of the principal. Conditions like these are what provide a great opportunity for agents to cheat. This fraud arises because of the human nature of self-interest, has limited thinking regarding future understanding, and will always avoid risk (risk averse). Factors related to self-interest are pressure, ability and arrogance, while factors related to risk averse are opportunity and rationalization (Aprillia, 2017).

Morally, the performance of a company in increasing profits for shareholders is the responsibility of management, management also has an interest in prospering itself (Ijudien, 2018). This condition causes an imbalance of information or asymmetrical information, so that this is a great opportunity for management to commit fraud, by manipulating the information presented in the financial statements.

\section{Stakeholder Theory}

Stakeholder theory is a theory which states that a company must provide benefits to stakeholders, and not only operate for its own interests (Ghozali \& Chariri, 2016). Stakeholders have the right to know information from organizational activities that can affect their power. Stakeholders consist of holders, customers, suppliers, government, society, shares, analysis and other parties. These users have various interests and roles regarding the organization in carrying out its operations. However, the survival of the company depends on the support provided by existing stakeholders (Deegan, 2009).

Company management can make efforts to reap the help and confidence of each stakeholder, and present the information that users want (Alfiani \& Rahmawati, 2019). In order for the information provided to be understood and not misinterpreted, it must be accompanied by an annual disclosure report. Flexible disclosure will enable the company to easily attract investors and provide trust and ensure creditors to increase their funding for the company (Amelia, 2017).

\section{Managerial Stock and Biological Asset}

\section{Disclosure}

Ownership concentration is a measure of the distribution of power in power taking. Ownership concentration shows how and who is in control of company ownership and who is in control of the business activities of a company in Kamijaya 2019. Antonia (2008) states that in terms of managers, they will try to maximize to prioritize company interests compared to personal interests. Because, the greater the manager's ownership in the company, the more productive the manager's actions are in maximizing disclosure of biological assets. Managerial ownership actively participates in company decision making, the better the company will be in disclosing financial statements in the notes to financial statements and the more productive the manager's actions are in maximizing information regarding disclosure of biological assets. The results of research conducted by Nasir et al. (2013) stated that managerial ownership has an effect on disclosure. Based on the theory and research results above, it can be concluded that the greater the percentage of company stock ownership, the more productive the manager's actions are in maximizing information regarding the disclosure of biological assets. Similar to the research results from Riski (2019), ownership concentration affects the disclosure of biological assets.

H1: Managerial Stock has an effect on biological assets disclosure

\section{Biological Asset Intensity and Biological}

\section{Asset Disclosure}

Biological asset intensity is a description of how much the company's investment value for biological assets. If a company has a high biological asset value, then the company tends to want to disclose it in the notes to the company's financial statements (Sa'diyah, 2019). Biological asset intensity describes how big the proportion of company investment is to its biological assets. The research results of Sakinatunnisak \& Budiwinarto (2020) state that biological asset intensity has a significant positive effect on disclosure of biological assets. In the results of Hayati's research (2020) there is a relationship 
which shows that biological asset intensity has a positive and significant effect on the disclosure of biological assets in agricultural companies in Indonesia. the higher the biological asset intensity The greater the urge to disclose more complete and clear information related to the biological assets owned by a company.A fair value measurement (Bahri, 2015) gives more considerablein obtaining a measure of financial performance or position for acertain period, especially for a long biological transformation. Withthe net gain from changes in the fair value of biological assets inthe income statement that can increase gross profit can increase netprofit which will affect the amount of the company's final capitalso that it will increase. According to research Bohušová et al.(2012), how biological assets are measured affects the financialof agricultural sector.

$\mathrm{H} 2$ : biological asset intensity has an effect on biological assets disclosure

\section{Firm Size and Biological Asset Disclosure}

Firm size is a measure of the size of the assets owned by the company because large companies generally have large total assets generally have large total assets and vice versa, if the small-scale companies generally have small total assets (Riski, 2019). So it can be concluded that the larger the company size, the greater the assets owned by the company and if the company is small, the total assets owned are also very small. In the results of research Aliffatun\&Sa'adah (2020) proves that company size affects the disclosure of biological assets in agricultural companies, here the size of the company can encourage company management to disclose information on its biological assets. The results of research by Selahudin\&Sfarhanaunitenedumy (2018) show that large companies can be influenced to disclose more information than small companies, that company size is positively related to mandatory disclosure because cleaner companies may have sufficient resources to bear the costs of disclosure and need to maintain their image and reputation.A study of (Pervan, 2012)conducted for the period2002-2010 and the results revealed that the size of the companyhas a significant positive (albeit weak) influence on companyprofitability. In addition, (Wufron, 2017) in his researchconcluded that simultaneously total assets and total sales havea significant effect on financial performance. Research resultshows that simultaneously the ESOP variable, leverage, andcompany size affect the company's performance as measuredby ROA and NPM. According to the Kakani et al. (2011) statesthat large companies are more profitable.

H3: Firm Size has an effect on biological assets disclosure

\section{RESEARCH METHOD}

This study applies a quantitative approach in compiling research, hypotheses, data, data analysis including its conclusions, until the writing applies aspects of measurement, calculation, formula, and numerical certainty. Judging from the underlying view of causal posibility, this approach provides a separation between simultaneous real temporal causes that start before ending in the appearance of its effects.

The analysis method used in this research is descriptive statistical analysis which is used to describe or describe data which can be seen from the standard deviation, the mean (mean), variance, minimum and maximum values. A good regression model is a regression model that uses the classical assumption test. The classic assumption test is carried out in 4 (four) ways, namely the normality test, multicollinearity test, autocorrelation test, and heteroscedasticity test before testing the hypothesis. This study uses multiple linear regression analysis. Multiple linear regression analysis was used to determine the effect of the independent variables on the dependent variable.The multiple regression model in this study is as follows:

$$
\begin{array}{ll}
\text { Y=a }+\mathrm{b} 1 \mathrm{X} 1+\mathrm{b} 2 \mathrm{X} 2+\mathrm{b} 3 \mathrm{X} 3+\mathrm{e} \\
\text { Where: } & \\
\mathrm{Y} & =\text { biological asset disclosure } \\
\mathrm{a} & =\text { Intercept } \\
\mathrm{X} 1 & =\text { Managerial Stock } \\
\mathrm{X} 2 & =\text { Biological Asset Intensity } \\
\mathrm{X} 3 & =\text { Firm Size }
\end{array}
$$

$\mathrm{e}=$ Residual value (the values of other variables not included in the equation)

\section{Population and Sample}

The population used in this study are agricultural companies listed on the Indonesia Stock Exchange during the 2016-2019 period. This study uses selected research samples from agricultural companies listed on the Indonesia Stock Exchange (IDX) during the 
2016-2019 period according to the specified criteria. Agricultural sector companies were chosen because of their tendency to be more complex in managing their biological assets than other sectors. The following are the criteria for selecting samples that have been determined.

Table 1. Sample Selection Criteria

\begin{tabular}{|l|c|}
\hline \multicolumn{1}{|c|}{ Criteria } & $\begin{array}{c}\text { Number of } \\
\text { Companies }\end{array}$ \\
\hline $\begin{array}{l}\text { Population of Agriculture companies } \\
\text { listed on the Indonesia Stock } \\
\text { Exchange for the period 2016-2019 }\end{array}$ & 19 \\
\hline $\begin{array}{l}\text { The company does not display } \\
\text { annual financial reports that are in } \\
\text { accordance with research in the } \\
\text { 2016-2019 period }\end{array}$ & 6 \\
\hline $\begin{array}{l}\text { Companies selected as samples for } 4 \\
\text { years }\end{array}$ & 52 \\
\hline
\end{tabular}

\section{Dependent variable}

Dependent variable in this study is the disclosure of biological assets. The Indonesian Accounting Association (IAI) states that biological assets state that biological assets are live plants or animals or agricultural plants that the company owns from past activities. The conclusion can be drawn from the above definition, namely, biological assets are assets in the form of live plants and livestock owned by agricultural companies that have characteristics due to the biological transformation of these assets.

Agricultural activity is an attempt to manage biological changes from biological assets to obtain a product that can be consumed and processed further so that biological assets are assets that are mostly used in agricultural activities. The biological changes that are felt by this biological asset are the special characteristics that distinguish this asset.

In accordance with IAS 41 (2003: 44) the characteristics inherent in biological assets can be divided into 2 , namely consumable assets or biological assets that can be consumed are as agricultural production. Biological assets will be harvested or sold, for example wheat, corn, trees planted for wood, meat production and livestock owned for sale. The second is Carrier assets are assets other than assets classified as depleted biological assets, for example vines and trees that produce wood while the trees are still alive, livestock to produce milk. Self-regeneration is a biological asset carrier that does not produce agricultural products.

This measurement at fair value less costs to sell at the point of harvest is used to measure agricultural products harvested from the entity's biological assets.The grouping of biological assets or agricultural products according to the attributes. Significant is the supporting material for measuring the fair value of biological assets or agricultural products. For example, an entity selects attributes that correspond to attributes used in a pricing market based on quality as well as age. To sell biological assets or agricultural products at a future date, the entity often enters into a contract, measuring the fair value of the contract price is not always relevant, because current market conditions reflect the fair value that the buying and selling market participants will undertake as a result, Because of this contract, the fair values of biological assets and agricultural products are not adjusted. In addition to measurement based on fair value, according to the minister of finance regulation No. 24 /PMK..03/2008 regarding depreciation of expenditures to acquire tangible assets owned or used in certain business fields, measurement of biological assets can also be done by identifying all expenditures to acquire these biological assets and then making them the value of the biological assets.Below is a list of biological asset disclosure items:

Table 2. Biological Asset Disclosure Items

\begin{tabular}{|c|c|l|c|}
\hline No & $\begin{array}{c}\text { Parag } \\
\text { raph }\end{array}$ & Disclosure Index & Score \\
\hline & & $\begin{array}{l}\text { Mandatory item: } \\
\text { Gains or losses arising } \\
\text { during the period: }\end{array}$ & 1 \\
\hline 1 & 26 & $\begin{array}{l}\text { Early recognition of } \\
\text { biological assets }\end{array}$ & 1 \\
\hline 2 & 26 & $\begin{array}{l}\text { Early recognition of } \\
\text { agricultural products }\end{array}$ & 1 \\
\hline 3 & 26 & $\begin{array}{l}\text { Changes in fair value } \\
\text { less costs to sell }\end{array}$ & 1 \\
\hline 4 & 30 & $\begin{array}{l}\text { Description of each } \\
\text { group of biological } \\
\text { assets }\end{array}$ & 1 \\
\hline 6 & 32 & $\begin{array}{l}\text { Explanation of } \\
\text { paragraphs }\end{array}$ & $\begin{array}{l}\text { Explanation of } \\
\text { paragraph disclosures }\end{array}$ \\
\hline 7 & 33 & $\begin{array}{l}\text { Description of the } \\
\text { company's activities in } \\
\text { each group of biological } \\
\text { assets }\end{array}$ & 1 \\
\hline
\end{tabular}




\begin{tabular}{|c|c|c|c|}
\hline & & $\begin{array}{l}\text { Explanation of non- } \\
\text { financial stages }\end{array}$ & \\
\hline 8 & 46 & $\begin{array}{l}\text { Assets available at the } \\
\text { end of the period }\end{array}$ & 1 \\
\hline 9 & 46 & $\begin{array}{l}\text { Agricultural produce } \\
\text { during this period }\end{array}$ & 1 \\
\hline 10 & 51 & $\begin{array}{l}\text { Assumptions and } \\
\text { methods used in } \\
\text { determining the fair } \\
\text { value of each } \\
\text { agricultural product at } \\
\text { the point of harvest and } \\
\text { each group of biological } \\
\text { assets }\end{array}$ & 1 \\
\hline 11 & 51 & $\begin{array}{l}\text { Fair value less costs to } \\
\text { sell agricultural } \\
\text { products harvested } \\
\text { during that period }\end{array}$ & 1 \\
\hline 12 & 49 & $\begin{array}{l}\text { Information relating to } \\
\text { restricted or pledged } \\
\text { biological assets }\end{array}$ & 1 \\
\hline 13 & 49 & $\begin{array}{l}\text { Commitments in the } \\
\text { development or } \\
\text { acquisition of biological } \\
\text { assets }\end{array}$ & 1 \\
\hline 14 & 49 & $\begin{array}{l}\text { Management strategies } \\
\text { related to the financial } \\
\text { risk of biological assets }\end{array}$ & 1 \\
\hline 15 & 46 & $\begin{array}{l}\text { Adjustments related to } \\
\text { changes in the carrying } \\
\text { amount of biological } \\
\text { assets at the beginning } \\
\text { and end of the period }\end{array}$ & 1 \\
\hline \multirow[t]{3}{*}{16} & 50 & $\begin{array}{l}\text { Reconciliation which } \\
\text { includes desegregation }\end{array}$ & 1 \\
\hline & 54 & $\begin{array}{l}\text { Additional disclosures } \\
\text { when fair value cannot } \\
\text { be measured reliably }\end{array}$ & \\
\hline & 54 & $\begin{array}{l}\text { Entities measure and } \\
\text { disclose biological } \\
\text { assets at their cost less } \\
\text { accumulated } \\
\text { depreciation and } \\
\text { accumulated } \\
\text { impairment }\end{array}$ & \\
\hline 17 & 54 & $\begin{array}{l}\text { Description of } \\
\text { biological assets }\end{array}$ & 1 \\
\hline 18 & 54 & $\begin{array}{l}\text { An explanation of why } \\
\text { fair value cannot be } \\
\text { measured reliably }\end{array}$ & 1 \\
\hline 19 & 54 & $\begin{array}{l}\text { Estimated extent of fair } \\
\text { value non-conformity }\end{array}$ & 1 \\
\hline 20 & 54 & $\begin{array}{l}\text { The depreciation } \\
\text { method used }\end{array}$ & 1 \\
\hline 21 & 54 & $\begin{array}{l}\text { The useful life or } \\
\text { depreciation rate used }\end{array}$ & 1 \\
\hline
\end{tabular}

\begin{tabular}{|c|c|c|c|}
\hline 22 & 54 & $\begin{array}{l}\text { The gross carrying } \\
\text { amount and the } \\
\text { accumulated } \\
\text { depreciation } \\
\text { (accumulated } \\
\text { impairment losses) at } \\
\text { the beginning and end } \\
\text { of the period }\end{array}$ & 1 \\
\hline 23 & 55 & $\begin{array}{l}\text { Recognition of gain or } \\
\text { loss from sale of } \\
\text { biological assets }\end{array}$ & 1 \\
\hline 24 & 55 & $\begin{array}{l}\text { Impairment loss, related } \\
\text { to discontinuation }\end{array}$ & 1 \\
\hline 25 & 55 & $\begin{array}{l}\text { Reversal for impairment } \\
\text { loss related to } \\
\text { discontinuation }\end{array}$ & 1 \\
\hline \multirow[t]{2}{*}{26} & 55 & $\begin{array}{l}\text { Depreciation Related to } \\
\text { Termination }\end{array}$ & 1 \\
\hline & 56 & $\begin{array}{l}\text { Related entity } \\
\text { disclosures - The fair } \\
\text { value of biological } \\
\text { assets previously } \\
\text { measured at cost less } \\
\text { accumulated } \\
\text { depreciation and } \\
\text { impairment losses are } \\
\text { reliably measurable } \\
\text { during the period }\end{array}$ & \\
\hline 27 & 56 & $\begin{array}{l}\text { Description of } \\
\text { biological assets }\end{array}$ & 1 \\
\hline 28 & 56 & $\begin{array}{l}\text { An explanation of why } \\
\text { fair value has been } \\
\text { measured reliably }\end{array}$ & 1 \\
\hline \multirow[t]{2}{*}{29} & 56 & $\begin{array}{l}\text { The effect of these } \\
\text { changes }\end{array}$ & 1 \\
\hline & 57 & $\begin{array}{l}\text { Government grant- } \\
\text { related entity } \\
\text { disclosures }\end{array}$ & \\
\hline 30 & 57 & Government grants & 1 \\
\hline 31 & 57 & $\begin{array}{l}\text { Recognition regarding } \\
\text { the nature and extent of } \\
\text { deep government grants }\end{array}$ & 1 \\
\hline 32 & 57 & financial statements & 1 \\
\hline \multirow[t]{3}{*}{33} & 57 & $\begin{array}{l}\text { The conditions are met } \\
\text { and other inherent } \\
\text { contingencies }\end{array}$ & 1 \\
\hline & & on government grants & \\
\hline & & $\begin{array}{l}\text { A significant reduction } \\
\text { in the level of } \\
\text { government grants }\end{array}$ & \\
\hline 34 & 42 & $\begin{array}{l}\text { Non-Mandatory but } \\
\text { recommended items: }\end{array}$ & 1 \\
\hline 35 & 43 & $\begin{array}{l}\text { A description of the } \\
\text { calculation of each } \\
\text { group of biological }\end{array}$ & 1 \\
\hline
\end{tabular}




\begin{tabular}{||l|c|l|c|}
\hline 36 & 40 & $\begin{array}{l}\text { assets, which } \\
\text { distinguishes them by: }\end{array}$ & $\begin{array}{l}\text { Consumable and bearer } \\
\text { asset }\end{array}$ \\
\hline 37 & NA & $\begin{array}{l}\text { Adult and immature } \\
\text { assets }\end{array}$ & 1 \\
\hline 38 & NA & $\begin{array}{l}\text { The amount of changes } \\
\text { in fair value less costs } \\
\text { to sell, affects profit or } \\
\text { loss due to physical } \\
\text { changes and changes in } \\
\text { price }\end{array}$ & 1 \\
\hline 39 & NA & $\begin{array}{l}\text { This information is } \\
\text { conveyed by biological } \\
\text { assets }\end{array}$ & 1 \\
\hline 40 & NA & $\begin{array}{l}\text { Information regarding } \\
\text { securities valuation }\end{array}$ & 1 \\
\hline
\end{tabular}

Source: PSAK-69 Agrikultur dan IAS 41

\section{Independent Variable}

Independent variables in this study are Biological Asset Intensity, Firm Size, and Managerial Ownership.The following is an explanation of each independent variable.

Biological assets that are assets owned by agricultural sector companies in the form of livestock or agricultural plants which have different characteristics from other assets because there is a biological transformation of the assets (Riski, 2019).Agricultural companies whose main assets are biological assets are required to carry out disclosure of biological assets. Related to information on biological assets, it can be useful for stakeholders to find out how big the proportion of company investment in biological assets is in a company.

Company size is a scale that can classify companies into large and small companies in a way that is assessed from the company's total assets, stock market value, average sales size and number of sales in a company (Duwu, 2018).Company size is a measure of the size of the assets owned by the company because generally large companies have large asset values and small-scale companies generally have small total assets (Riski, 2019).

Managerial ownership is the amount of share ownership by the management of the overall share capital of the company being managed. In this study, ownership is measured by the percentage of the number of shares owned by management (Nasir et al., 2013). This potential issue of interest causes the importance of a mechanism to be implemented to protect the interests of shareholders. The conflict of interest between the manager and the owner gets bigger when the manager's ownership of the company gets smaller. In this case the manager will try to maximize his own interests compared to the interests of the company. Conversely, if the greater the ownership of the manager in the company, the more productive the manager's actions are in maximizing the disclosure of biological assets.

The table below is the measurement and operationalization of the dependent and independent variables.

Table 3. Operational Variables

\begin{tabular}{|c|c|c|c|}
\hline Variable & Indicator & $\begin{array}{c}\text { Measure } \\
\text { ment }\end{array}$ & Source \\
\hline $\begin{array}{l}\text { Biological } \\
\text { Asset } \\
\text { Disclosure } \\
\text { (Y) }\end{array}$ & $\begin{array}{l}\text { Number } \\
\text { ofcompletenes } \\
\text { s items that are } \\
\text { fulfilled and } \\
\text { the number of } \\
\text { items that may } \\
\text { be fulfilled in } \\
\text { the disclosure } \\
\text { of biological } \\
\text { assets }\end{array}$ & $\begin{array}{l}\text { Index } \\
\text { Wallace } \\
=\mathrm{n} / \mathrm{k} \quad \mathrm{x} \\
100 \%\end{array}$ & $\begin{array}{l}\text { Arison } \\
\text { (2017) }\end{array}$ \\
\hline $\begin{array}{l}\text { Managerial } \\
\text { Stock }\end{array}$ & $\begin{array}{l}\text { The number of } \\
\text { managerial } \\
\text { shares and the } \\
\text { number of } \\
\text { shares } \\
\text { outstanding }\end{array}$ & $\begin{array}{l}\text { number of } \\
\text { manageria } \\
1 \text { shares } / \\
\text { number of } \\
\text { shares } \\
\text { outstandin } \\
g\end{array}$ & $\begin{array}{l}\text { Nasir } \\
\text { (2017) }\end{array}$ \\
\hline $\begin{array}{l}\text { Biological } \\
\text { Asset } \\
\text { Intensity }\end{array}$ & $\begin{array}{l}\text { Assets in the } \\
\text { form of live } \\
\text { animals and } \\
\text { plants and } \\
\text { total assets }\end{array}$ & $\begin{array}{l}\text { (AsetBiol } \\
\text { ogis)/(Tot } \\
\text { al Aset) }\end{array}$ & $\begin{array}{l}\text { Riski } \\
\text { (2019) }\end{array}$ \\
\hline Firm Size & Total Asset & $\begin{array}{l}\text { Ln (Total } \\
\text { Asset }\end{array}$ & $\begin{array}{l}\text { Aliffatun } \\
(2020)\end{array}$ \\
\hline
\end{tabular}

\section{RESULT AND DISCUSSION}

Result Statistic Descriptive Analysis

Table 4. Statistic Descriptive

\begin{tabular}{|l|l|l|l|l|l||}
\hline Var & Min & Max & Mean & STD Deviatiom & N \\
\hline$X 1$ & 0,00 & 0,87 & 0,244 & 0,2020 & 52 \\
\hline$X 2$ & 0,5 & 0,62 & 0,300 & 0,16375 & 52 \\
\hline$X 3$ & 25,43 & 31,40 & 29,73 & 1,321 & 52 \\
\hline$Y$ & 0,53 & 0,69 & 0,598 & 0,0377 & 52 \\
\hline
\end{tabular}

Source : processed data SPSS (2021) 
Based on the results of descriptive statistical tests with a total sample of 52 companies, the results show that the biological asset intensity variable has a minimum value of 0.5 , maximum value of 0.62 , amean value of 0.300 and a standard deviation value 0.16375 . Variable firm size has minimum value of 25,43 , maximum value of 31,40 , mean value of 29,73 and a standard deviation value 1,321. Variable MangerialStock has minimum value of 0,00 , maximum value of 0,244 , mean value of 0,244 and a standard deviation value 0,2020 . And the last variable biological asset disclosure has minimum value of 0,53 , maximum value of 0,69 , mean value of 0,598 and a standard deviation value 0,0377 .

Table 5. Classical Asumption

\begin{tabular}{|c|c|c|c|c|}
\hline & $\begin{array}{c}\text { Norma } \\
\text { lity }\end{array}$ & $\begin{array}{c}\text { Multicol } \\
\text { inearity }\end{array}$ & $\begin{array}{c}\text { Heteros } \\
\text { kedastisi } \\
\text { ty }\end{array}$ & $\begin{array}{c}\text { Autocor } \\
\text { elation }\end{array}$ \\
\hline$X 1$ & $\sqrt{ }$ & $\sqrt{ }$ & $\sqrt{ }$ & $\sqrt{ }$ \\
\hline$X 2$ & $\sqrt{ }$ & $\sqrt{ }$ & $\sqrt{ }$ & $\sqrt{ }$ \\
\hline$X 3$ & $\sqrt{ }$ & $\sqrt{ }$ & $\sqrt{ }$ & $\sqrt{ }$ \\
\hline$Y$ & $\sqrt{ }$ & $\sqrt{ }$ & $\sqrt{ }$ & $\sqrt{ }$ \\
\hline
\end{tabular}

source: processed data SPSS (2021)

The results of table 4 show that all variables are free from the classical assumption test. this shows that hypothesis testing can be done.

Based on the results of the multiple regression test, the results of the study are as shown in Table 5 below :

Table 6. Hypothesis Test

\begin{tabular}{|l|c|c|c|}
\hline \multicolumn{1}{|c|}{ Model } & B & T & Sig \\
\hline 1 (Constant) & 0,742 & 3,459 & 0.01 \\
\hline $\begin{array}{l}\text { Managerial } \\
\text { Stock }\end{array}$ & $-0,082$ & $-2,561$ & 0,14 \\
\hline $\begin{array}{l}\text { Biological } \\
\text { Asset Intensity }\end{array}$ & $-0,167$ & $-2,921$ & 0,006 \\
\hline Firm Size & $-0,03$ & $-0,399$ & 0,692 \\
\hline & & & \\
\hline
\end{tabular}

source: processed data SPSS (2021)

Multiple regression test results shown in Table 5 show that the biological asset intensity variable measured using Assets in the form of live animals and plants and total assetshas a significance value of $0.006<0.05$. This means that $\mathrm{H} 2$ has a significant effect on biological asset disclosure. Next, firm size is measured based total asset company has a signifinace value of $0,692>0,005$. This shows that firm size does not have a significant effect on biological asset disclosure. The managerial stock variable has a significance of $0.14>0.05$, which means that X3 has not significant positive effect biological asset disclosure.

\section{Discussion}

Magnitude of the intensity of biological assets in agricultural companies does not guarantee the extent of disclosure of biological assets carried out by these companies. It is evident from the results of research that shows that the score of disclosure of biological assets in agricultural companies, both with large biological asset intensity and small biological asset intensity, is not much different. This happens because biological assets are the main assets owned by agricultural companies, so that no matter what the circumstances are, the company will still disclose its biological assets. Another reason is the accounting standard related to disclosure of biological assets that was only passed in December 2015 and will only become effective in January 2018, which causes companies with a greater intensity of biological assets to think that several matters related to their biological assets are not required to be disclosed in annual reports. This is in line with the results of research conducted by (Pramitasari, 2018) which states that biological asset intensity has a significant negative effect on the disclosure of biological assets.

Agricultural companies that have large total assets sometimes do not necessarily have large biological assets, so this shows that agricultural companies that have large total assets do not guarantee that they will pay attention to the breadth and completeness of disclosure of their biological assets compared to companies that have total assets. in small quantities. Agricultural companies with small total assets, they also have the same interest in attracting the attention of external parties, so that agricultural companies that have small total assets will still disclose their biological assets at least in order to compete with large companies. Another reason is that the new agricultural accounting standards will become effective in January 2018, which has led several large 
companies to assume that certain matters related to their biological assets are not required to be disclosed in their annual reports. Thus, the size of agricultural companies, whether small, medium or large, does not have an effect on the disclosure of biological assets. This research is in line with the results of research conducted by (Alfiani, 2019; Kusumadewi, 2018) which states that company size has no effect on the disclosure of biological assets.

The results of tests carried out using SPSS 20 show thatManagerial ownership has no effect on asset disclosurebiological. Managerial stock variable is proxied by measurementcomparing the number of managerial shareholdings with the numberthe outstanding shares multiplied by one hundred. Managerial ownershipis that the increase in managerial ownership in the companyencourage managers to create optimal company performanceand motivate managers to act wisely because they participatebear the consequences for their actions (Wiriadinata, 2015). More and morethe greater the ownership of managers in the company, the more productive it isthe manager's actions in maximizing disclosure of biological assets.This research is contradictory in research (Nasir, 2013) and(Antonia, 2008) which states that managerial ownershipeffect on disclosure. It means when a companyhave managerial ownership, it is not necessarily a companyprovides a wealth of information regarding disclosures of biological assets.Based on the definition of managerial ownership is a conditionindicates that the manager owns shares in the company. Principalas a party who does not follow the day to day operations of the companywant the widest possible disclosure of information. For that in orderthe manager feels responsible so it is given a numbershares to company managers in the hope that the managerscan disclose information in the company for the sake ofprincipal (Anisah, 2018). But the results of this study provethat the percentage of shares owned by directors and directors is notensure that the manager party to provide relevant informationdisclosure of biological assets to the principal. This research is consistentwith research conducted by (Wiriadinata, 2015) and (Anisah,2018) which states that managerial ownership has no effectto the disclosure of biological assets.
Simultaneously test explain that biological asset intensity, firm size, and managerial ownership affect the disclosure of biological assets. Biological asset intensity, supported by a theory which explains that biological assets are assets in the form of animals or live plants which are the main assets owned by agricultural companies. As the main asset, the large proportion of a company's investment in its biological assets should also be disclosed in the annual report as a form of reporting by agricultural companies on assets it has managed, which are a source of profit for agricultural companies. Agricultural companies with large total assets tend to disclose more extensive and complete information, but it does not rule out the possibility for small companies to disclose their biological assets completely in an effort to attract the attention of external parties and to compete with large companies.

\section{CONCLUSION}

The results of the above discussion can be concluded that firm size and managerial stock no significant effect on biological asset disclosure, while biological asset intensity has a significant positive effect on biological asset disclosureagricultural companies listed on the Indonesian stock exchange in 2016-2019.Based on the limitations found, the researchers expectthe following suggestions can complement further research is expected to use the populationan even larger number of studies, using the most recent yearsand extending the observation period of the research in order to providean up-todate overview of disclosures of biological assets, add test variablesothers that may affect the disclosure of biological assets, agricultural companies are expected to express moredetails of biological assets managed by the company. Starting from the momeninitial recognition, at the time of the harvest, and when the assets are alreadyproduce and immature. So that users reportfinance bias is clearer.

\section{REFERENSI}

Al, A., \& Ahmed, A. (2012). Disclosure of Financial Reporting and Firm Structure as a Determinant: A Study on the Listed Companies of DSE. ASA University Review, 6(1), 43-60.

Abrar, M. (2019). Pengaruh Biological Asset Intensity, Ukuran Perusahaan, Konsentrasi 
Kepemilikan Manajerial, Jenis Kap Dan Profitabilitas Terhadap Pengungkapan Aset Biologis. Fakultas Ekonomi dan Bisnis. Institut Informatika dan Bisnis Darmajaya. Bandar Lampung.

A. (2012). Disclosure of Financial Reporting and Firm Structure as a Determinant: A Study on the Listed Companies of DSE. ASA University Review, 6(1).

Amelia, F. (2017). Pengaruh Biological Asset Intensity, Ukuran Perusahaan, Konsentrasi Kepemilikan dan Jenis KAP Terhadap Pengungkapan Aset Biologis. Fakultas Ekonomi. Universitas Andalas. Padang.

Azzahra, V., Luthan, E., \& Fontanella, A. (2020). Determinan Pengungkapan Aset Biologis ( Studi Empiris pada Perusahaan Agriculture yang Terdaftar di Bursa Efek Indonesia). Journal of Economic and Business, 4 (1).

Bahri, S.W. (2015), Evaluasi penilaian aset biologi dan pengaruhnya terhadap laporan keuangan. Artikel Ilmiah Mahasiswa, 4(1), 91-95. Bohušová, H., Svoboda, P., Nerudová, D. (2012), Biological assets reporting: Is the increase in value caused by the biological transformation revenue? Agricultural Economics (Czech Republic), 58(11), 520-532.

Chavent, M., Ding, Y., Fu, L., Stolowy, H., \& Wang, H. (2006). Disclosure and determinants studies: An extension using the divisive clustering method (DIV). European Accounting Review, 15(2), 181218.

Daat, S. C., \& Andriati, H. N. (2018). Pengaruh Biological Asset Intensity, Ukuran Perusahaan, Konsentrasi Kepemilikan, Jenis Kap, Dan Profitabilitas Terhadap Biological Asset Disclosure. Jurnal Akuntansi \& Keuangan Daerah, 56-75.

Deegan, C. (2009). Financial accounting theory McGraw Hill. North Ryde, NSW, Australia.

Ditjenbun. (2020). Peluang Ekspor Perkebunan Masih Bertahan. Diakses darihttp://ditjenbun.pertanian.go.id/peluangekspor-perkebunan-masih-bertahan/
Dr. Widodo. (2020). METODOLOGI PENELITIAN Populer dan Praktis (1st ed.). Depok:PT Rajagrafindo Persada.

Duwu. (2018). Pengaruh Biological Asset Intensity, Ukuran Perusahaan, Konsentrasi Kepemilikan, Jenis Kap, Dan Profitabilitas Terhadap Biological Asset Disclosure. Jurnal Akuntansi Dan Keuangan Daerah, 13(2), 56-75.

Duwu, M. I., Daat, S. C., \& Andrianti, H. N. (2018). Pengaruh Biological Asset Intensity, Ukuran Perusahaan, Konsentrasi Kepemilikan, Jenis KAP, dan Profitabilitas terhadap Biological Asset Disclosure (pada Perusahaan Agrikultur yang terdaftar di Bursa Efek Indonesia Periode 2012-2016). Jurnal Akuntansi Dan Keuangan Daerah, 13(2).

Dzingai, I., Fakoya, M.B. (2017), Effect of corporate governance structure on the financial performance of johannesburg stock exchange (JSE)- listed mining firms. Sustainability, 9, 867.

Eltanto, D. P. (2014). Perlakuan Akuntansi dan pph atas industri agrikultur. Tax \& Accounting Review, 4(1), 93.

Ghozali, I., \& Chariri, A. (2016). Teori Akuntansi International Financial Reporting Systems (IFRS).Universitas Diponegoro, Semarang

Gonçalves, R., \& Lopes, P. (2014). Firm-specific determinants of agricultural financial reporting. Procedia - Social and Behavioral Sciences, $\quad 110, \quad 470-481$. https://doi.org/10.1016/j.sbspro.2013.12.891

Gustria, U., \& Sebrina, N. (2020). Pengaruh profitabilitas, ukuran perusahaan, dan jenis kap terhadap pengungkapan aset biologis. Jurnal Eksplorasi Akuntansi, 2(1), 23622372.

Hayati, K. (2020). Pengaruh Biological Asset Intensity, Growth, Leverage, Dan Tingkat Internasional Terhadap Pengungkapan Aset Biologis. Jurnal Eksplorasi Akuntansi, 2(2), 2638-2658.

Hesty Erviani, Z., Dewi, R., \& Aeling Setya, A. 
(2019). Pengungkapan Aset Biologis Pada Perusahaan Agrikultur Di Indonesia Serta Faktor Yang Mempengaruhinya. Jurnal Borneo Cendekia, 3(2), 40-46.

Hidayah, N., Zarkasyi, W. (2017), The effect of human resources management competency and the role of culture on accrual accounting implementation effectiveness and the impact on quality of accounting information. European Research Studies Journal, 20(4), 183-199

Indonesia Stock Exchange, n d. (n.d.). Laporan Keuangan dan Tahunan.

Www.Idx.Co.Id.Diakses

darihttps://www.idx.co.id/perusahaantercatat/laporan-keuangan-dan-tahunan/.

Jensen, M. C., \& Meckling, W. H. (1979). Theory of the firm: Managerial behavior, agency costs, and ownership structure. Journal of Financial Economics, 3(4).

Kusumadewi, A. A. (2018). Pengaruh Biological Asset Intensity dan Ukuran Perusahaan terhadap Pengungkapan Aset Biologis (Pada Perusahaan Perkebunan yang Terdaftar di BEI Periode 2017). Perpustakaan Fakultas Ekonomi dan Bisnis Unpas Bandung.

Nasir, A., Kurnia, P., \& Hakri, T. D. (2013). Pengaruh Kepemilikan Manajerial, Leverage, Profitabilitas, Ukuran, dan Umur Perusahaan Terhadap Pengungkapan Informasi Pertanggungjawaban Sosial Perusahaan Pada Perusahaan Food And Beverage Yang Terdaftar di BEI. Jurnal Ekonomi, 21(04).

Owusu-Ansah, S. (1998). The impact of corporate attribites on the extent of mandatory disclosure and reporting by listed companies in Zimbabwe. The International Journal of Accounting, 33(5), 605-631.

Pervan, M. (2012). Influence of Firm Size on Its Business Success. Croatian Operational Research Review, 3(1), 213-223.

Putri, M. O., \& Siregar, N. Y. (2019). Pengaruh Biological Asset Intensity, Ukuran Perusahaan, Kepemilikan Manajerial, Dan Jenis Kap Terhadap Pengungkapan Aset
Biologis. Jurnal Akuntansi Dan Keuangan, 10(2), 44. https://doi.org/10.36448/jak.v10i2.1288

Safitri, S. (2013). Perlakuan Akuntansi Aset Biologis Hubungannya dengan Kualitas Informasi Keuangan Pada Perkebunan Nusantara VI Jambi (Persero). Jurnal Penelitian Jurusan Akuntansi Fakultas Ekonomi YPTK Padang.

Sakinatunnisak, S. E., \& Budiwinarto, K. (2020). Analisis Pengaruh Biological Asset Intensity Dan Profitabilitas Terhadap Pengungkapan Aset Biologis Pada Perusahaan Agrikultur. Jurnal Ekonomi dan Kewirausahaan 20(2), 178-185.

Sari, K. R., \& Rita, M. (2011). Historical Cost vs Fair Value Accounting atas Pengakuan dan Penilaian Tanaman Perkebunan. Jurnal Eksistansi Politeknik Negeri Sriwijaya Jurusan Akuntansi, 3, 362-370.

Selahudin, N. F., \& Sfarhanaunitenedumy. (2018). Biological Assets: The Determinants of Disclosure. Jurnal Internasional 10(3), 170-179.

Sugiyono. (2017). Metode Penelitian Kuantitatif, Kualitatif dan R\&D. Bandung: Alfabeta, CV. 53(9).

Sugiyono. (2019). Penelitian Pendidikan Pendekatan Kuantitatif Kualitatif R\&D. Bandung: Alfabeta (19th ed.).

Suwardjono. (2014). Teori Akuntansi Perekayasaan Pelaporan Keuangan (edisi ketiga). BPFE Yogyakarta. (Tiga).

Sa'diyah, L. D., Dirmayati, M., \& Murniati, W. (2019). Pengaruh Biological Asset Intensity, Ukuran Perusahaan, dan Tingkat Internasionalisasi Terhadap Pengungkapan Aset Biologis ( Pada Perusahaan Agrikultur Yang Terdaftar Di Bursa Efek Indonesia Periode 2013-2017 ). Progress Conference, 2(July), 291-304.

Trina, Z. I. (2017). ANALISIS PERLAKUAN AKUNTANSI DAN DEPLESI ASET BIOLOGIS BERDASARKAN IAS 41 PADA PERUSAHAAN PETERNAKAN (Studi Kasus Pada CV. Milkindo Berka Abadi 
Kepanjen).

Tyas, E. L. A., \& Fachriyah, N. (2012). Evaluasi Penerapan Standar Akuntansi Keuangan dalam Pelaporan Aset Biologis (Studi Kasus Pada Koperasi "M"). Jurnal Ilmiah Mahasiswa FEB, 1(1).

Utomo, R., \& Khumaidah, N. L. (2014). Perlakuan Akuntansi Aset Biologis (Tanaman Kopi) Pada PT. Wahana Graha Makmur-Surabaya. GEMA EKONOMI. Jurnal Fakultas Ekonomi, 3(1), 85-95.
Wufron, W. (2017), Pengaruh ukuran perusahaan terhadap kinerjakeuangan serta implikasinya terhadap nilai perusahaan pada perusahaan manufaktur yang terdaftar di bursa efek indonesia. Jurnal Wacana Ekonomi, 34, 14-21.

Zufriya, C., Putri, N. K., Farida, Y. N., \& Soedirman, U. J. (2020). Pengaruh Biological Asset Intensity , Konsentrasi Kepemilikan Dan Profitabilitas. Jurnal Akuntansi Syariah4(2), 271-282. 